\title{
The influence of side vent length on instrument flexural fatigue of three endodontic irrigating needles
}

\author{
Bryant William Stowe \\ West Virginia University
}

Follow this and additional works at: https://researchrepository.wvu.edu/etd

\section{Recommended Citation}

Stowe, Bryant William, "The influence of side vent length on instrument flexural fatigue of three endodontic irrigating needles" (2009). Graduate Theses, Dissertations, and Problem Reports. 2808. https://researchrepository.wvu.edu/etd/2808

This Thesis is protected by copyright and/or related rights. It has been brought to you by the The Research Repository @ WVU with permission from the rights-holder(s). You are free to use this Thesis in any way that is permitted by the copyright and related rights legislation that applies to your use. For other uses you must obtain permission from the rights-holder(s) directly, unless additional rights are indicated by a Creative Commons license in the record and/ or on the work itself. This Thesis has been accepted for inclusion in WVU Graduate Theses, Dissertations, and Problem Reports collection by an authorized administrator of The Research Repository @ WVU. For more information, please contact researchrepository@mail.wvu.edu. 


\title{
THE INFLUENCE OF SIDE VENT LENGTH ON INSTRUMENT FLEXURAL FATIGUE OF THREE ENDODONTIC IRRIGATING NEEDLES
}

Bryant William Stowe, D.D.S.

Thesis submitted to the School of Dentistry at

West Virginia University

in partial fulfillment of the requirements

for the degree of

\author{
Master of Science \\ in \\ Endodontics
}

Michael D. Bagby, D.D.S., M.S., Ph.D., Chair

C. Russell Jackson, D.D.S., M.S.

Thomas F. Razmus, B.S., D.D.S., M.S.

Department of Endodontics

Morgantown, West Virginia

2009 


\title{
ABSTRACT \\ THE INFLUENCE OF SIDE VENT LENGTH ON INSTRUMENT FLEXURAL FATIGUE OF THREE ENDODONTIC IRRIGATING NEEDLES
}

\author{
Bryant William Stowe, D.D.S.
}

The purpose of this in-vitro study was to compare the influence of the side vent length on flexural fatigue and subsequent failure of three endodontic irrigating needles. Twenty ProRinse Endodontic Irrigation Probes, twenty-three Max-i-Probes, and twenty Vista-Probe Irrigating Tips were used in this study. All three irrigating needles are 30gauge, have a side-vented port, and are safe-ended. After all side vent lengths were measured and recorded, each needle was subjected to flexing cycles of $30^{\circ}$ until flexural fatigue occurred and the instrument permanently failed. Data were analyzed using a oneway ANOVA and Tukey HSD test. Results indicate the Vista-Probe required a significantly greater number of cycles to produce flexural fatigue as compared to the ProRinse and Max-i-Probe irrigating probes $(\mathrm{p}<.0001)$. However, the length of the side vent as it relates to flexural fatigue within each individual needle group did not appear to be statistically significant $(\mathrm{p}>.05)$. 
To my amazing wife, Tiffani, my incredible children, Beckham and Madeline, my mom, dad, family, and friends - your examples have inspired me, your support has granted me the possibility of achieving all, and your love and patience have given me motivation to make my life, and hopefully yours, better. I love you. 


\section{ACKNOWLEDGMENTS}

Thanks to Dr. C. Russell Jackson for giving me the opportunity to follow dreams and provide mentorship, laughter, and friendship along the way. The more I get to know you, the more I realize your love for your residents and the incredible sacrifice-both time-related and financially_ that you have offered. Your gift to maintain this endodontic residency has fulfilled numerous dreams. Thank you.

Thanks to Dr. Bagby for his essential help with this thesis-providing the foundation for the master's thesis, offering opinion on various aspects of the design of the study, and providing the statistical analyses. Your help has been appreciated and invaluable. Hopefully, Volkswagen Vanagons will never die...

Thanks to Dr. Razmus for serving on my thesis committee and continuing to provide invaluable education to countless dental students. One day they will recognize the great gift educators such as you have provided them.

Thanks to Cathy and Gina for the many long appointments through lunch and at the end of the day. Your unique personalities provided the spice that allowed for no dull moments while treating patients. You both will be missed.

Thanks to Katherine Gottschalk, Melody Gwilliam, and Shawn Hussion for their smiling faces, desire to improve our department, and most importantly, work ethics.

Thanks to Dr. Ryan Burleson for making the first year memorable and for all of the unbelievable, outlandish stories.

Thanks to Dr. Mark Richey for his friendship and happy, carefree demeanor. I've learned more about coffee by listening to you and $\mathrm{Al}$ — who knew anything could be smooth, woody, and nutty all at the same time? May you and I always have a "Gold Rush" to look forward to.

Thanks to Drs. Gavin Criser and Spencer Stiles for the crosswords, the karaoke, and more importantly, the great times this past year. I thank you for your friendships. Hobbes! 
Finally, thanks to Dr. Albert Tomsic. The past two years have been memorable. I have appreciated your years of experience and have admired the meticulous treatment you have provided your patients. I have been lucky to share this residency with someone who has similar practice philosophies - someone who cares more for quality than quantity. Neither you nor I broke records, but I'm confident in knowing that our patients will be grateful nevertheless. Thank you again. 


\section{TABLE OF CONTENTS}

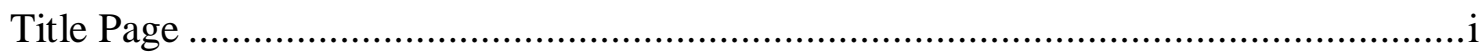

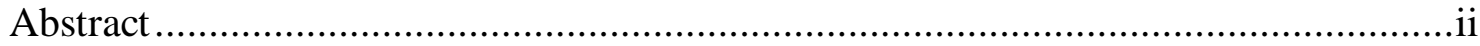

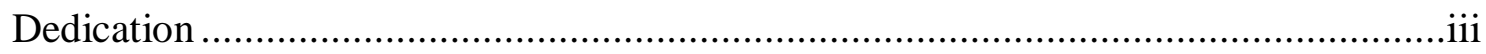

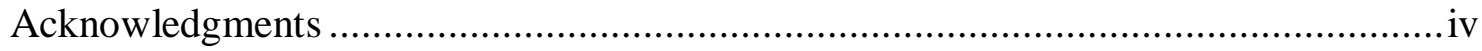

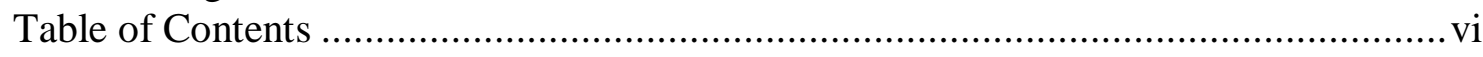

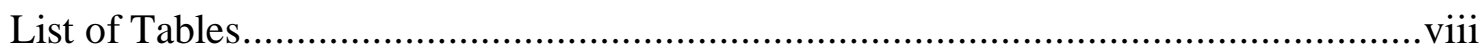

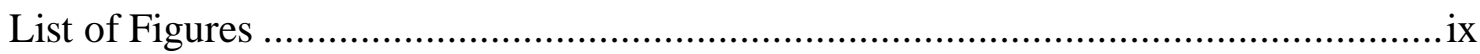

Chapter I

Introduction

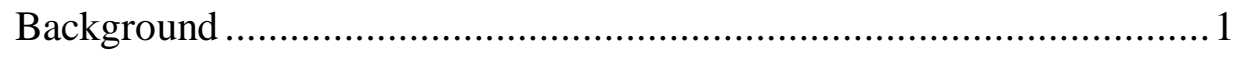

Statement of the Problem...............................................................

Significance of the Problem..............................................................

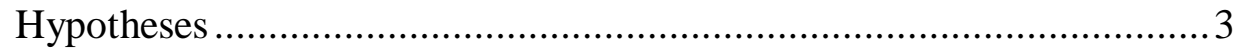

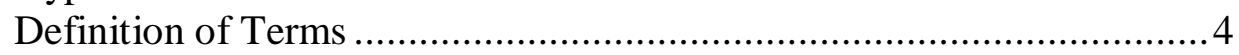

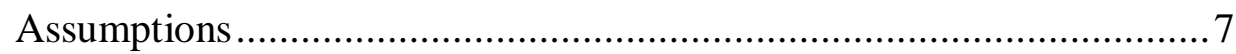

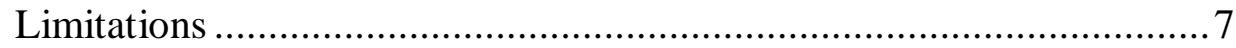

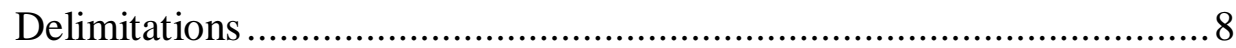

Chapter II

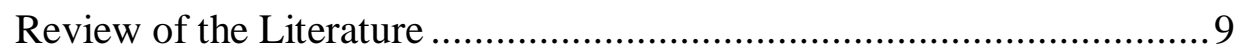

Chapter III

Methods and Materials

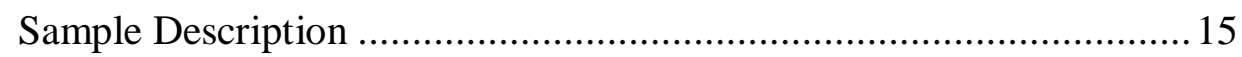

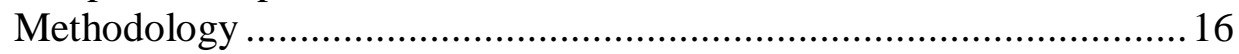

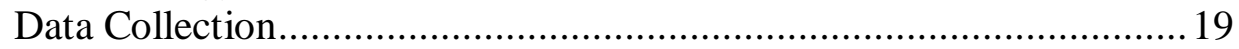

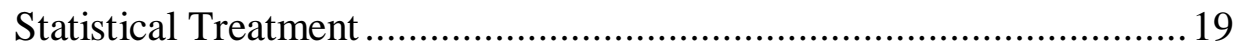

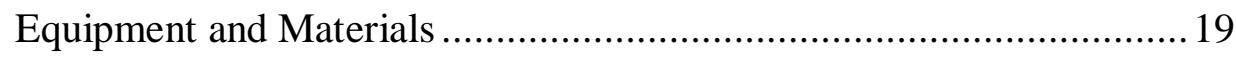

Chapter IV

Results and Discussion

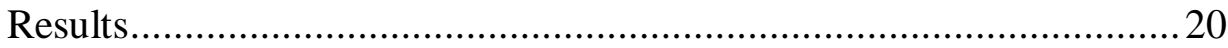

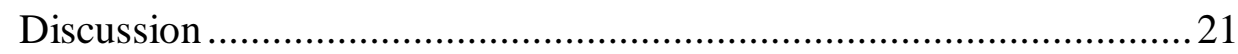

\section{Chapter V}

Summary and Conclusion

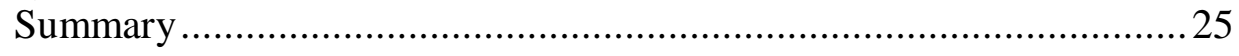


Conclusion ........................................................................ 26

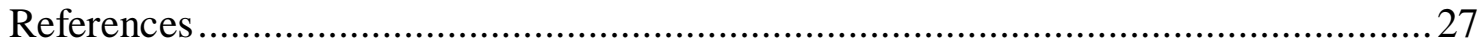

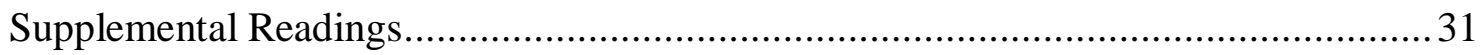

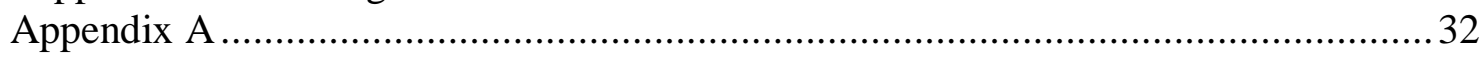

Data for Max-i-Probe Irrigating Needles ....................................................... 33

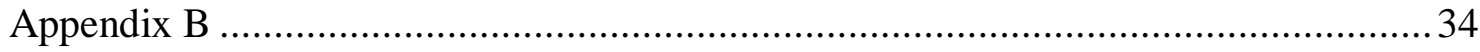

Data for ProRinse Irrigating Needles ............................................................. 35

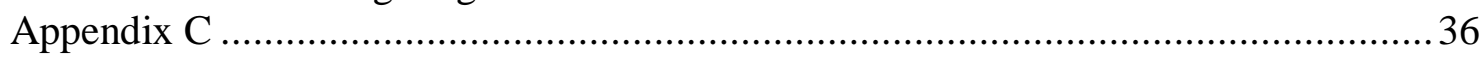

Data for Vista-Probe Irrigating Needles ........................................................ 37

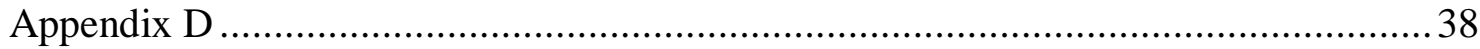

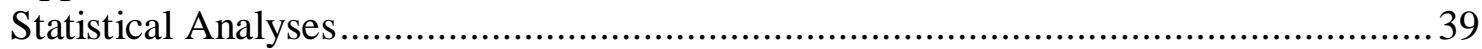

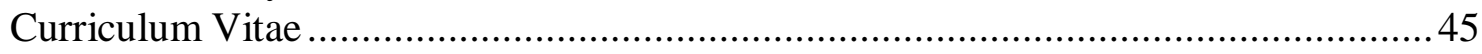




\section{LIST OF TABLES}

Table 1. Data for Max-i-Probe Irrigating Needles .............................................. 32

Table 2. Data for ProRinse Irrigating Needles .................................................. 34

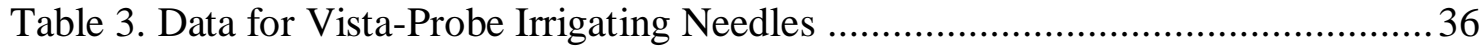




\section{LIST OF FIGURES}

Figure 1. Radiograph of tooth \#30 before endodontic therapy. ............................... 3

Figure 2. Radiograph of tooth \#30 following endodontic therapy............................. 3

Figure 3. Enlarged view of ProRinse, Vista-Probe, and Max-i-Probe irrigating needles.................................................................... 15

Figure 4. Identifying terms used for side vent length measurement. ........................ 16

Figure 5. Equation used to determine side vent length..................................... 16

Figure 6. Photograph of design model...................................................... 17

Figure 7. Schematic diagram illustrating the testing phase. ............................... 18

Figure 8. Bent irrigating needle during testing phase........................................ 18

Figure 9. Failed and separated irrigating needle. ......................................... 18

Figure 10. Average side vent length in millimeters. ........................................ 20

Figure 11. Average number of cycles required for failure................................ 21 


\section{CHAPTER I}

\section{INTRODUCTION}

\section{BACKGROUND}

Bacteria and their influence on dental pulp and periradicular pathosis have long been studied. Numerous studies have proven that vital pulps in root canal systems exposed to a bacteria-free oral environment maintain viability and do not induce pathosis $(1,2)$. In contrast, dental pulps that are exposed to oral environments laden with bacteria eventually succumb to pulpal necrosis and more importantly develop periradicular pathosis. The inability and failure to properly eradicate bacteria from the root canal system continue to be primary causes for endodontic failure.

The importance of adequately cleaning and shaping the root canals is paramount in effective root canal therapy. The quality of obturation and thus, long-term success of the tooth depend on a properly instrumented and debrided root canal system.

Mechanical instrumentation of the root canal system does reduce the bacterial load as was reported by Byström and Sundqvist in their study in 1981. They instrumented root canals without the aid of any antibacterial irrigant and then cultured the canals $(3,4)$. This bacterial reduction is incomplete and insufficient without the aid of an irrigant as delivered by an irrigating needle. The irrigant of choice may be debated, but some agreement exists on the method of irrigation necessary to provide the best irrigation and debridement.

Root canal diameter plays an important role in allowing proper flushing of the entire root canal length (5), and the irrigant will eventually reach the terminus of the canal if instrumented to an ISO \# 30 endodontic hand file (6). Others determined that the irrigating needle provided maximum mechanical flushing efficacy when placed within one millimeter of the canal's working length $(7,8)$.

The result of many years of evolving recommendations, typical irrigation consists of using copious amounts of an irrigant (typically sodium hypochlorite) to regularly flush 
debris from the canals and to introduce irrigant throughout the entire canal system. Of great importance is proximity of the irrigating needle to the canal terminus to ensure that irrigant is reaching all aspects of the canal and that any debris is effectively flushed out. Irrigation is performed multiple times throughout the cleaning and shaping phases of endodontic therapy.

The introduction of irrigating needles or probes with much smaller diameters has permitted better access to the root canal system terminus, and the introduction of a sidevented port has created a more efficient, safer instrument designed for proper flushing of the root canal system. The combination of smaller diameters and side-vent ports has created a very advantageous and effective endodontic irrigating instrument.

\section{STATEMENT OF THE PROBLEM}

Safe-ended side-vented endodontic irrigating needles may fail and separate in the root canal system, and if so, does the size of the side-vent create a greater risk for flexural fatigue and subsequent instrument failure and separation when comparing the Max-iProbe, ProRinse, and Vista-Probe irrigating needle?

\section{SIGNIFICANCE OF THE PROBLEM}

With such emphasis placed on eradicating bacteria and flushing debris from the root canal system terminus during endodontic therapy, irrigating needles of ever decreasing diameter are gaining wider acceptance and growing in use. Three such needles are the Max-i-Probe, ProRinse, and Vista-Probe irrigating. All three are available in similar lengths and gauges and feature safe-ended, side-vented tips.

There has been report of instrument failure (Figs. 1 and 2) at the location of the side-vented port of these irrigating needles (9). The ability to retrieve and the location of a separated instrument greatly influence the prognosis of root canal therapy and can reduce the success rate by as much as $19 \%$ (10). Many studies address hand and engine- 
driven rotary file failure and separation, but no such study exists evaluating any such failure in irrigating needles.

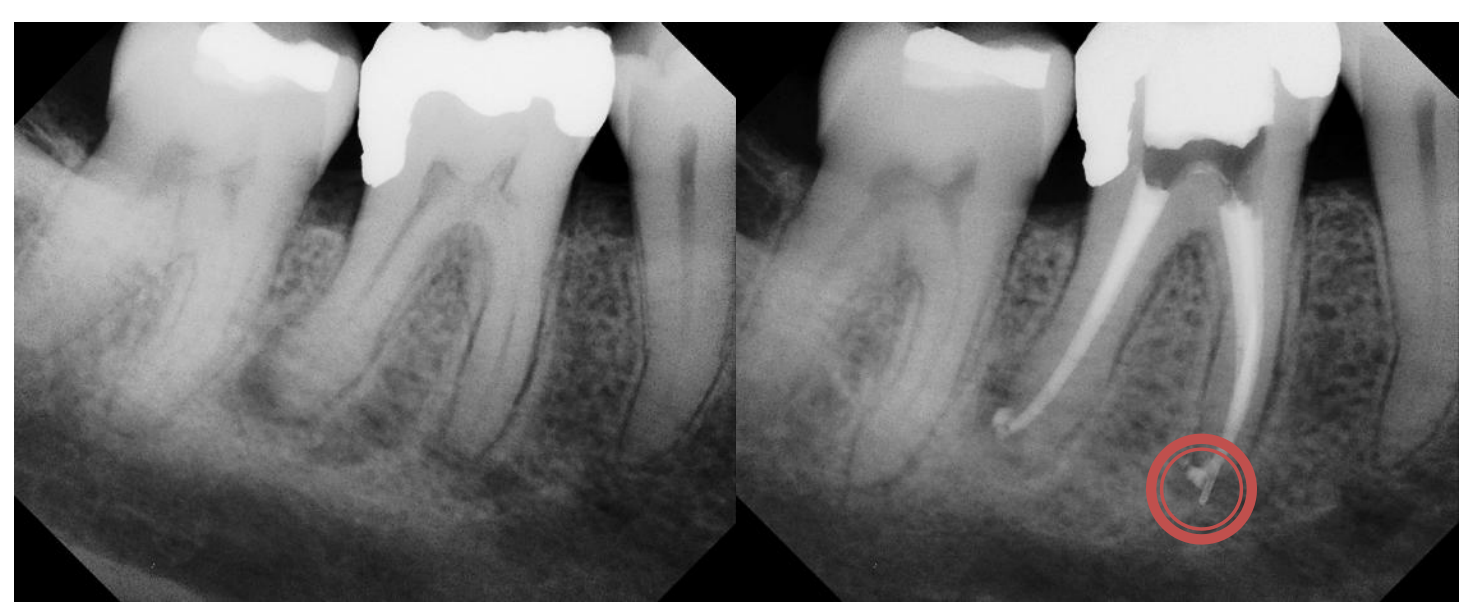

Figure 1. Radiograph of tooth \#30 before endodontic therapy.
Figure 2. Radiograph of tooth \#30 following endodontic therapy-note the separated irrigating needle in the mesial root.

Because instruments of this design appear to present so many favorable characteristics and advantages, use is widespread, and as increasingly smaller instrument diameters are used, failure will likely become more prevalent. Thus, it is imperative to understand that if failure and separation occur with this type of instrument, how size of the side-vent influences the risk of failure.

\section{HYPOTHESES}

(1) There is statistically no significant difference in instrument failure as it relates to flexural fatigue in the Max-i-Probe, ProRinse, and Vista-Probe irrigating needles when comparing side vent length to the number of cycles required for failure, and (2) no irrigating needle will require a significantly greater number of cycles and thus be clinically "safer" as it relates to flexural fatigue. 


\section{DEFINITION OF TERMS}

Apex - the tip or uppermost point of the tooth

Apical seat-lack of a complete barrier but the presence of a constricture

Apical stop-barrier at the preparation end of the root canal system

Apical terminus - the most apical location within the instrumented canal; nearly corresponds to apical stop or seat

Cyclic fatigue - permanent structural change that occurs in a material subjected to fluctuating stress and strain during numerous cycles

Dentin plug — an obstructing mass of dentinal debris resembling a stopper

Endodontic failure (root canal therapy failure) - description of an endodontically treated tooth that is symptomatic, fails to show radiographic signs of periapical/periradicular healing, or both

Endodontic hand file-instrument used to file and ream root canal walls

Endodontic success (root canal therapy success) — description of an endodontically treated tooth that is asymptomatic and that shows radiographic signs of periapical/periradicular healing

Endodontic therapy (root canal therapy) — a dental procedure aimed at saving a tooth by removing the pulpal contents and obliterating the root canal space with a filling material

ENDO-VU—an acrylic block with a simulated root canal 
Engine-driven endodontic rotary file-instrument used to file and ream root canal walls powered by a dental handpiece

File size-ISO-determined dimension of endodontic files that describe the diameter of the file's tip - usually, in hundredths of millimeters

File taper-ISO-determined gradual increase in diameter from file tip to a point 16 millimeters from the tip. For each millimeter of length up the file, the file's diameter increases a specific size (e.g. .02 taper file increases .02 millimeters in diameter for each millimeter in length)

Flexural fatigue - physical property expressed by the number of times a material can be bent on itself through a prescribed angle before it ruptures or loses its ability to recover

Flushing (of debris) — to cleanse or wash out with a rush of fluid

Foramen - small opening or orifice through which the nerve and vascular tissue enter and exit the tooth

Gauge - the diameter of a slender object, such as a needle

Gutta Gauge-instrument that has ISO-sized holes used to verify diameters of gutta-percha

Instrument failure-inability of an instrument to perform its normal function; fracture or giving away under stress

Instrument fracture - breakage of an instrument or the state of an instrument being broken 
Instrument separation—instrument division or detachment into two or more parts

Irrigant—liquid used during irrigation; sodium hypochlorite is the most commonly used endodontic irrigant

Irrigating needle - needle of various gauge used during irrigation to deliver the irrigant into the canal

Irrigation - therapeutic flushing with a stream of liquid

ISO - International Organization for Standardization

Lot number-number assigned to an instrument so as to identify the batch or run in which it was manufactured

Master Apical File - the file used to set the final diameter of the apical region preparation; the last file instrumented to the working length

Max-i-Probe - endodontic irrigating probe or needle from Rinn-Dentsply featuring side-vented safe-ended tip

Obturation-closure by filling of the root canal space

Periapical/Periradicular - descriptive term of the area and/or tissues surrounding the apex of the tooth

ProRinse - endodontic irrigating probe or needle from Tulsa Dental featuring a side-vented safe-ended tip

Root canal system - the space of the tooth that contains the pulpal tissue from the pulpal chamber to the canal terminus at the apex 
Safe-ended-descriptive term of an irrigating needle that has no opening at its terminus and has a round end

Side-vented - descriptive term of an irrigating needle that has an opening on the side of the instrument as opposed to an opening at its terminus

Vista-Probe - endodontic irrigating probe or needle from Vista Dental featuring a side-vented safe-ended tip

Vent — an opening or relief in an irrigating needle for the escape of a fluid or gas

Working length-length determination used to instrument the root canal system and at which subsequent obturation will be completed

\section{ASSUMPTIONS}

(1) Flexing of irrigating needles in vitro mimicked in vivo usage. (2) Incidence of flexural fatigue failure and separation of an irrigating needle during testing is reproducible during true clinical usage. (3) Any assumed increase in risk between the Max-i-Probe, ProRinse, and Vista-Probe as it relates to flexural fatigue is also inferable to in vivo use.

\section{LIMITATIONS}

(1) This in-vitro study attempted to simulate one aspect of clinical conditions present during endodontic irrigation-flexing of the probe or needle; however, conditions may vary from true in-vivo conditions. (2) Throughout the manufacturing process, the irrigating needles undergo quality assurance, but exact metal characteristics in each irrigating needle may vary. (3) Because the makeup of each probe might differ, 
individual probe or needle ability to endure repeated flexure without fatigue might be increased or decreased irrespective of side vent size. (4) Inherent flaws induced during the manufacturing process of each irrigating needle might increase or decrease the numbers of cycles needed for flexural fatigue and instrument failure.

\section{DELIMITATIONS}

(1) To allow for nearly identical testing situations for each irrigating needle, each needle was flexed using the same gutta gauge and protractor. (2) A random sample of various irrigating needles from numerous lot numbers were used to ensure a wide variety. (3) Visible inspection of each irrigating needle was performed to detect any possible manufacturer's defects and thus, removal from the sample pool. (4) Each irrigating needle was subjected to the same degree of flexure $\left(30^{\circ}\right.$ to $0^{\circ}$ and $-30^{\circ}$ to $\left.0^{\circ}\right)$. (5) Each flexing cycle was performed in the same horizontal plane. (6) Flexing cycles were repeated until the needle experiences flexural fatigue and separates. 


\section{CHAPTER II REVIEW OF LITERATURE}

Teeth have been treated endodontically for close to one hundred fifty years, as Dr. Hudson has been credited with performing some of the first recorded non-surgical root canal therapy in 1862 (11). The techniques and materials have changed throughout the years as all clinicians have aimed at improving the success and efficiency of endodontic therapy.

Though root canal therapy continues to evolve, bacteria and their removal continue to lie central to the focus of endodontics. In 1965, Kakehashi et al. (1) proved that dental pulps exposed to germ-free oral environments do not necrose and in turn do not develop periapical pathosis. Only when bacteria are present and are allowed to gain access to the pulp space might pulp tissue necrosis occur and a periapical lesion develop.

This idea is further supported by work done by Sundqvist in 1976. He proved that apical periodontitis and related pathologies could only be detected in teeth that had bacteria present in the root canal systems. Necrotic teeth due to trauma that were sterile had no signs of periapical radiolucency. Adding to this idea, he also suggested that the probability of pain increased with the number of bacterial species present-strong proof for bacterial synergism (4).

Möller's group in 1981 provided proof again that the etiology of periapical pathology begins with bacteria. By exposing dental pulps in monkeys, they were able to prove that sterile teeth in sterile oral cavities will stay sterile, and only when bacteria are present will periapical pathology develop (2).

The role of bacteria in endodontic and periapical pathology is irrefutable. Thus, many studies were designed to determine if bacteria actually are found within the root canal system. Baumgartner, et al. (12) collected freshly extracted teeth that had been extracted due to large carious lesions that invaded the pulpal space. After incubating the 
teeth in an anaerobic environment, the root canal space was cultured to determine the presence or absence of bacteria. The apical five millimeters was rife and teemed with bacterial life.

Seltzer and Farber (13) and Siqueira (14) have both presented review articles to summarize the role of bacteria in endodontic therapy as well as to highlight the importance of reducing bacterial levels as low as possible. In 1997, Sjögren et al. (15) evaluated how the outcome of endodontic therapy was affected by bacterial infection. The results showed that endodontic success was much higher in cases that had close to complete eradication of bacteria from the canal. Those cases that yielded a positive culture from the root canals at time of obturation had much higher rates of failure.

Thus, the goal to promote higher rates of success must be to remove bacteria. Many clinicians have held the opinion that mechanical instrumentation alone will sufficiently remove bacteria. In 1981, Byström and Sundqvist (3) showed that instrumentation greatly reduced the bacterial load but did not entirely remove any potential pathogens. Dalton et al. (16) echoed the results of others by proving that stainless-steel hand file instrumentation or nickel-titanium rotary instrumentation resulted in cleaner canals but not sterile canals. Neither cleaning method surpassed the other cleaning ability; more importantly, neither method was able to rid the canals completely of bacteria. Siqueira et al. (17) provided results that suggest the ineffectiveness of relying on only mechanical instrumentation to clean bacteria from the canals, regardless of instrumentation technique.

Debris left in the canals prior to obturation has also been shown to affect success and treatment outcome. Holland et al. (18) showed that plugging the apical third of the canal with infected dentin chips leads to undesirable tissue reactions, and thus, infected dentin chips should be removed prior to obturation. Yusuf (19) presented similar results. Foreign material of dentin and cementum chips extruded through the apical foramen of the tooth into the periapical tissue elicited active inflammation. In contrast to the previous two studies, Ariizumi et al. (20) showed that the presence of dentinal chips isn't as important as the virulence of the chips or how densely they are packed.

Because mechanical instrumentation alone is ineffective at bacterial removal, irrigation has been employed to bridge the gap and improve endodontic therapy. 
Numerous studies have evaluated the role of different irrigants and various methods of irrigation.

Sodium hypochlorite is the most commonly used endodontic irrigant in use as it contains most of the ideal irrigant properties (21). Dakin used sodium hypochlorite in 1918 at a very weak concentration to debride and clean wounds of servicemen (21). Coolidge is credited with being the first to use sodium hypochlorite to irrigate root canals in 1919 (14). Senia et al. (22) compared the efficacy of saline versus sodium hypochlorite at tissue dissolution and reached the conclusion that sodium hypochlorite does dissolve tissue. Harrison (23) provided further support for the use of sodium hypochlorite. Not only did sodium hypochlorite effectively dissolve necrotic tissue, it more importantly possessed antimicrobial activity and effectively removed organic debris from the root canal. Concentration of the irrigant of choice has been the topic of much research. Hand et al. (24) proved that $5.25 \%$ sodium hypochlorite was the most effective concentration.

While the choice of irrigant appears to be nearly unanimous, the method of irrigation remains a topic of disagreement. Considering irrigation, Walton and Torabinejad (25) said, "Perhaps the most important factor is the delivery system and not the irrigating solution per se." Others have suggested that the volume of irrigant is more important than the concentration or type of irrigant $(26,27)$.

Various studies have provided results that offer minimum requirements that must be met for effective irrigation to occur. Ram (5) determined that the diameter of the canal was more influential on irrigation than the type of irrigant used. To allow irrigant to passively reach the apical terminus of the canal and in theory have any action, Salzgeber and Brilliant (6) suggested that the canal must be worked to a minimum apical size of 0.3 millimeter (\# 30 file).

Altering designs of irrigating needles and adjusting physical characteristics of irrigants have been attempted to improve irrigation. Goldman et al. (28) tested one of the first safe-ended irrigating needles against conventional designs to discover that the safeended design was very effective. A similar study that did not include a safe-ended irrigating needle showed that of the four designs used, none performed better at removing 
a radioactive gel from a simulated canal (29). Surface tension of the irrigant was reduced by Abou-Rass et al. (30), which improved flow only during the first five minutes.

Chow (8) proved that not much irrigation or flushing occurs beyond one millimeter from the tip of an irrigating needle. Thus, to effectively irrigate and flush, the needle must be taken to the desired area - the apical terminus. These findings were preceded by work from Abou-Rass and Piccinino (7) that showed a 30-gauge anesthetic needle was much more effective at removing debris than a 23-gauge Monoject syringe. Proximity to the debris and bacteria is critical, and a smaller gauge of needle allows closer approximation.

Large gauge needles have some benefit (27). As the gauge of the irrigating needle increases, the syringe grows easier to depress. This relationship is inversely proportional. As a result of their findings, they determined that the most effective irrigation was with blunted, open-ended, large needles at full length. With larger-gauged needles at full length, safety becomes an issue. Bradford et al. (31) showed that binding the irrigating needle in the canal could create unsafe, higher irrigating pressures. Also, needles with larger gauges create higher pressures. As pressures increase and proximity to the apical foramen nears, sodium hypochlorite accidents become a concern.

Numerous case reports are present throughout the literature of irrigating accidents (32-36). These detail individual reports of sodium hypochlorite accidents and subsequent sequelae. Many clinicians avoid the use of sodium hypochlorite for fear of extruding irrigant through the foramen. The need exists for an irrigating needle design effective at irrigation and flushing at the apical foramen while still providing improved safety.

Rounded, safe-ended tips on the irrigating needle appear to be beneficial. In 1983, Sinanan et al. (37) compared three irrigating systems and determined two safeended irrigating needles effectively flushed debris. The open-ended syringe flushed poorly and extruded irrigant beyond the apical foramen. Teplitsky et al. (38) echoed these results by detailing the poor performance of the traditional, open-ended irrigating needle.

In 1995, Kahn et al. (39) evaluated a relatively new irrigating needle that had a safe end and side vent. The results showed that this irrigating needle was the most effective instrument used to flush the simulated canal. This instrument was even 
effective at placing other materials in the canal (40). Sedgley et al. $(41,42)$ used this same needle in two studies in 2004 and 2005. The first study described a new method to quantify bacteria. This technique proved the efficacy of this design's flushing ability. The second study reiterated those results found by Chow in 1983. Flushing and irrigation was most effective at the apical terminus and not as effective five millimeters from the same terminus. Important to note is that this needle design allowed placement at the apical terminus and adequate irrigation and flushing at this location.

Further support for this instrument design was given by Vinothkumar et al. (43), who proved that the side vent was significantly effective at removing bacteria from inoculated canals. Hsieh et al. (44) supported these findings, as well as those of previous investigators.

The small gauges available to clinicians allow for placement of the irrigating needle at the apical terminus. However, as the irrigating needles are forced to negotiate canals that are anything but straight, instrument failure and separation become points of interest. Though no studies have been performed evaluating irrigating needle failure and separation, Kahn et al. (39) suggested the importance of such a study to evaluate the likelihood of such complication. Many studies have been performed to evaluate the impact of instrument failure, but most of these studies focused on endodontic file failure.

The issue of instrument failure has been of importance for over thirty years and continues to be the topic of much research. Segall et al. (45) suggested a standard for manufacturing quality after he evaluated numerous files for various defects and undesirable debris. Sotokawa (46) evaluated the causes of instrument failure and suggested changes to employ to minimize future difficulty. Though many standards have been implemented, instruments will continue to fail.

Strindberg (10) reported a $19 \%$ decrease in success in teeth that had separated instruments. Crump and Natkin (47) suggested a possible alteration in success rate but that the location of the embedded instrument piece and if the canals had been appropriately cleaned prior to the separation were of greater importance. Using a separated file as method for obturation was suggested by Tamse and Katz (48). This technique was criticized heavily by peers. 
The need for a safe-ended, side-vented irrigating needle that allows for complete penetration to the apical terminus is obvious. The ability of such an irrigating needle to properly flush and irrigate has been proven throughout numerous studies, but the safety and incidence of instrument failure and separation is unknown. 


\section{CHAPTER III}

\section{METHODS AND MATERIALS}

\section{SAMPLE DESCRIPTION}

Twenty ProRinse irrigating needles, twenty-three Max-i-Probe irrigating needles, and twenty Vista-Probe irrigating needles were acquired (Fig. 3). All were 30-gauge irrigating needles. Prior to inclusion in the study, each needle was inspected with a measuring microscope to inspect for any obvious manufacturing defect, which would render the needle inherently weak. A needle with such a flaw would be discarded before use in a typical dental office setting as well. In addition, all sixty-three needles were randomly acquired from various lot numbers to ensure randomization and variability in each needle to be tested.

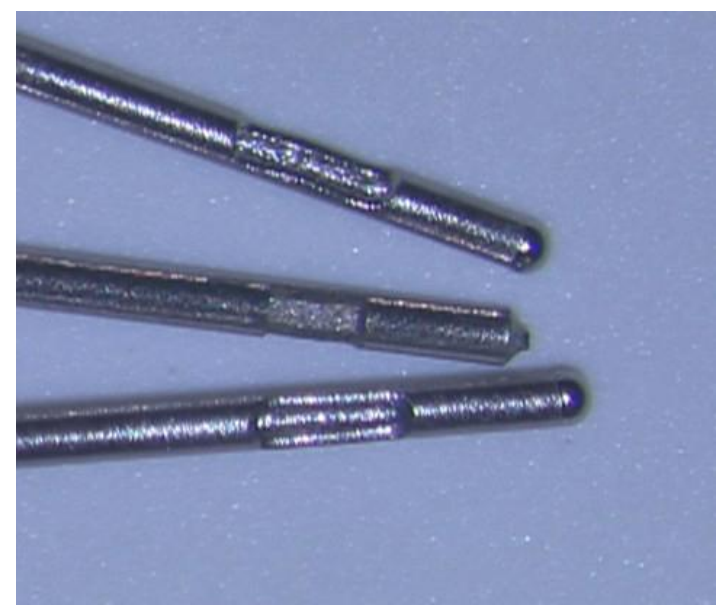

Figure 3. Enlarged view of ProRinse, Vista-Probe, and Max-i-Probe irrigating needles (top to bottom). 


\section{METHODOLOGY}

Before the needles were subjected to any testing, each needle was visibly inspected for any flaws. After the irrigating needle was approved, the lot number was recorded and masking tape placed to cover any identifying label in order to ensure no bias during the recording or testing phases.

The length of each side vent was measured in millimeters using a measuring microscope. The length was calculated by measuring the difference between the distance from the tip of the needle to the proximal or beginning location of the side vent and the distance from the tip of the irrigating needle to the end or distal location of the side vent (Figs. 4 and 5).

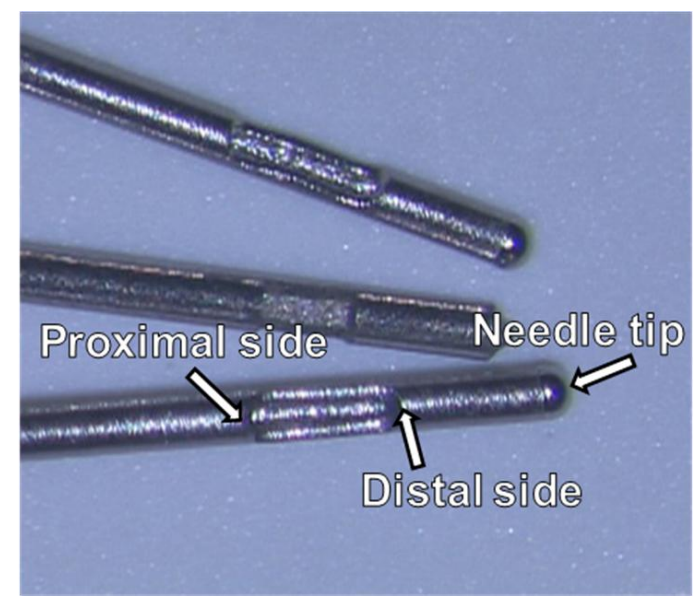

Figure 4. Identifying terms used for side vent length measurement.

Side vent length $=$ (length of needle tip to proximal side) - (length of needle tip to distal side)

Figure 5. Equation used to determine side vent length.

Each needle's size was verified with the gutta gauge by ensuring each probe would easily pass through the $.35 \mathrm{~mm}$ gauge and not pass through the $.25 \mathrm{~mm}$ gauge. Additionally, each needle was oriented so the side vent was positioned in a downward position at $270^{\circ}$. The needle was then securely placed into the $.30 \mathrm{~mm}$ gauge of the gutta 
gauges. The gutta gauge, with the securely-bound needle, was then placed atop a protractor measuring $360^{\circ}$ (Fig. 6).

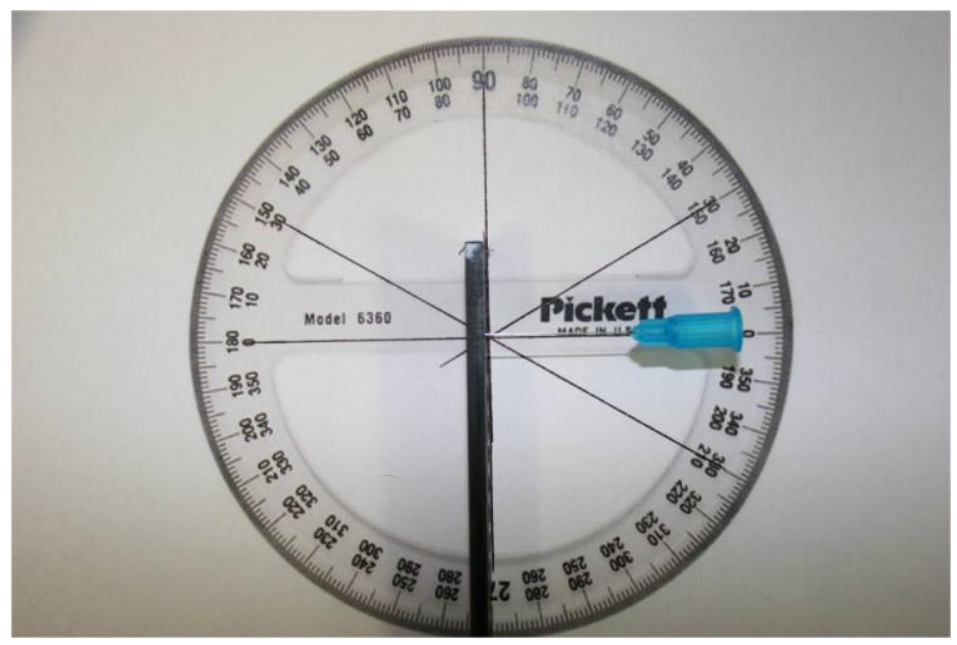

Figure 6. Photograph of design model.

Markings were used to verify correct, standardized position of the gutta gauge and accompanying needle. Lines were drawn to indicate $30^{\circ}$ and $-30^{\circ}$ (i.e. $330^{\circ}$ ).

Once standardized position was verified, each needle was manually grasped using the thumb and forefinger and subjected to cyclic flexing. One cycle consisted of bending the needle from $0^{\circ}$ to $30^{\circ}$ and back to $0^{\circ}$. The second cycle consisted of bending the needle from $0^{\circ}$ to $-30^{\circ}$ and then back to $0^{\circ}$ (Fig. 7). Careful to perform each flex in the horizontal plane and to maintain the orientation of the side vent, each needle was subjected to cyclic flexing until flexural fatigue occurred and the needle completely separated. The number of cycles required for failure was then recorded. 


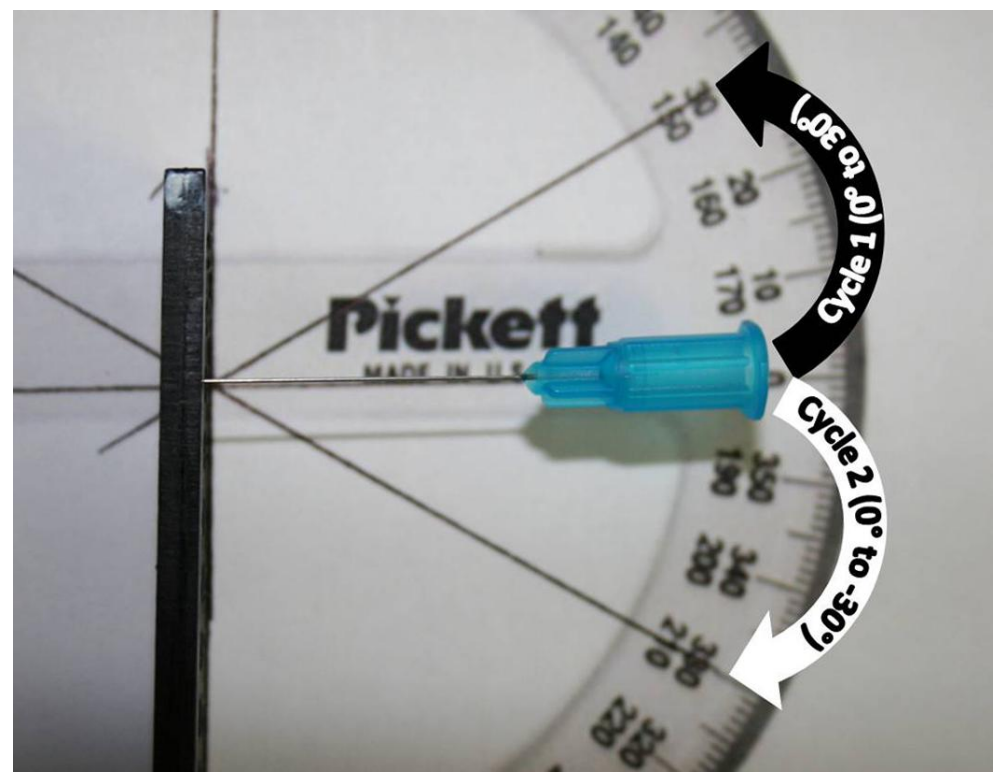

Figure 7. Schematic diagram illustrating the testing phase. The needle hub (shown in blue) was grasped with the thumb and forefinger and flexed in the horizontal plane in a back and forth motion (i.e. cycle 1 followed by cycle 2 , then repeated) until failure occurred.

Once the testing was complete, each needle was visually examined using magnification to confirm failure and to identify the location of separation (Figs. 8 and 9).

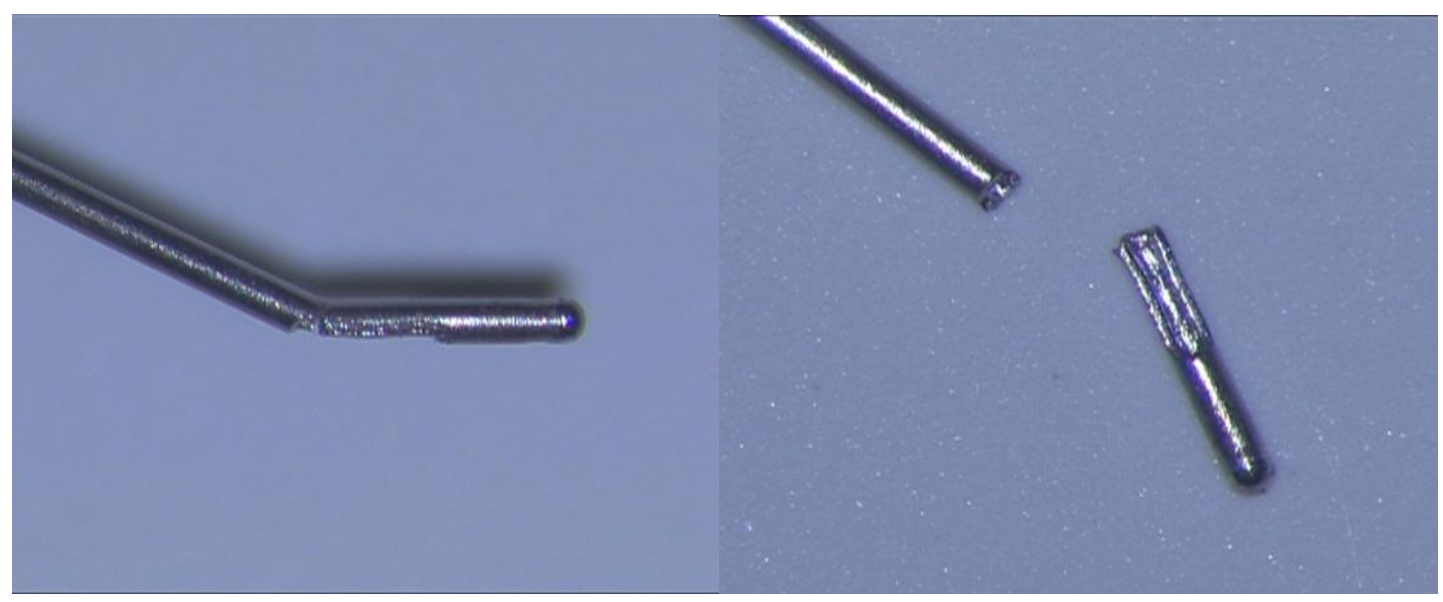

Figure 8. Bent irrigating needle during testing phase.
Figure 9. Failed and separated irrigating needle. 


\section{DATA COLLECTION}

A spreadsheet was created that identified each needle according to manufacturer and lot number and allowed for a blinded number. Using the blinded numbers, the two different length measurements were entered into the spreadsheet to provide the length of each side vent. After each needle was successfully tested for flexural fatigue and failure, the number of cycles was recorded. Additionally, the location was recorded if different from the side vent.

\section{STATISTICAL TREATMENT}

The side vent length and cycles required for failure were analyzed using bivariate fit. Also, a one-way ANOVA was used to determine if a significant difference existed between groups and Tukey's HSD test was used to identify which groups were significantly different. Significance was determined at $\mathrm{P}<0.05$.

\section{EQUIPMENT AND MATERIALS}

- Max-i-Probe endodontic irrigating probes (Dentsply Rinn, Eglin, IL)

- Vista-Probe Irrigating Tips endodontic irrigating probes (Vista Dental, Racine, WI)

- ProRinse Endodontic Irrigation Probes (Tulsa Dental, Tulsa, OK)

- Gaertner measuring microscope (Gaertner Scientific Corporation, Chicago, IL)

- Gutta Gauge (Tulsa Dental, Tulsa, OK)

- $360^{\circ}$ Protractor (Pickett Industries, Springhill, LA) 
CHAPTER IV

\section{RESULTS AND DISCUSSION}

\section{RESULTS}

The mean side vent length for the Max-i-Probe, ProRinse, and Vista needles was $0.956 \pm 0.064 \mathrm{~mm}, 0.920 \pm 0.040 \mathrm{~mm}$, and $0.600 \pm 0.027 \mathrm{~mm}$ respectively (Fig. 10)

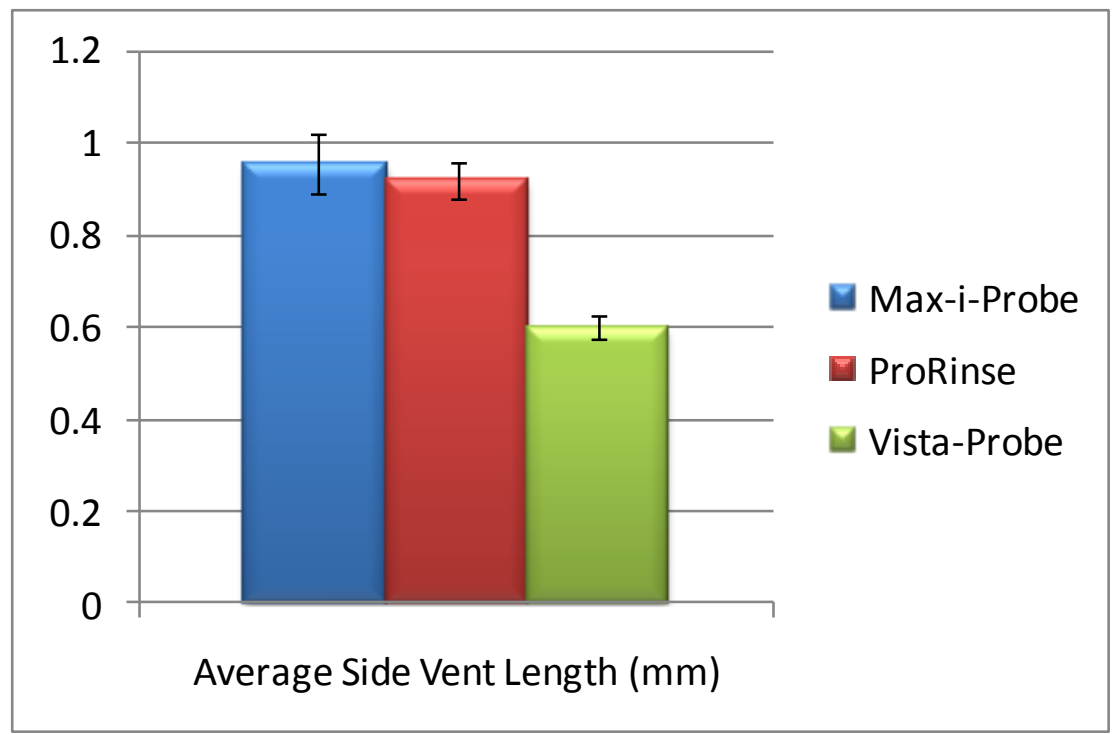

Figure 10. Average side vent length in millimeters.

The mean number of cycles required for flexural fatigue and failure for the Max-iProbe, ProRinse, and Vista-Probe needles was $38.5 \pm 10,41.0 \pm 11$, and $101.7 \pm 31$ respectively (Fig. 11). 


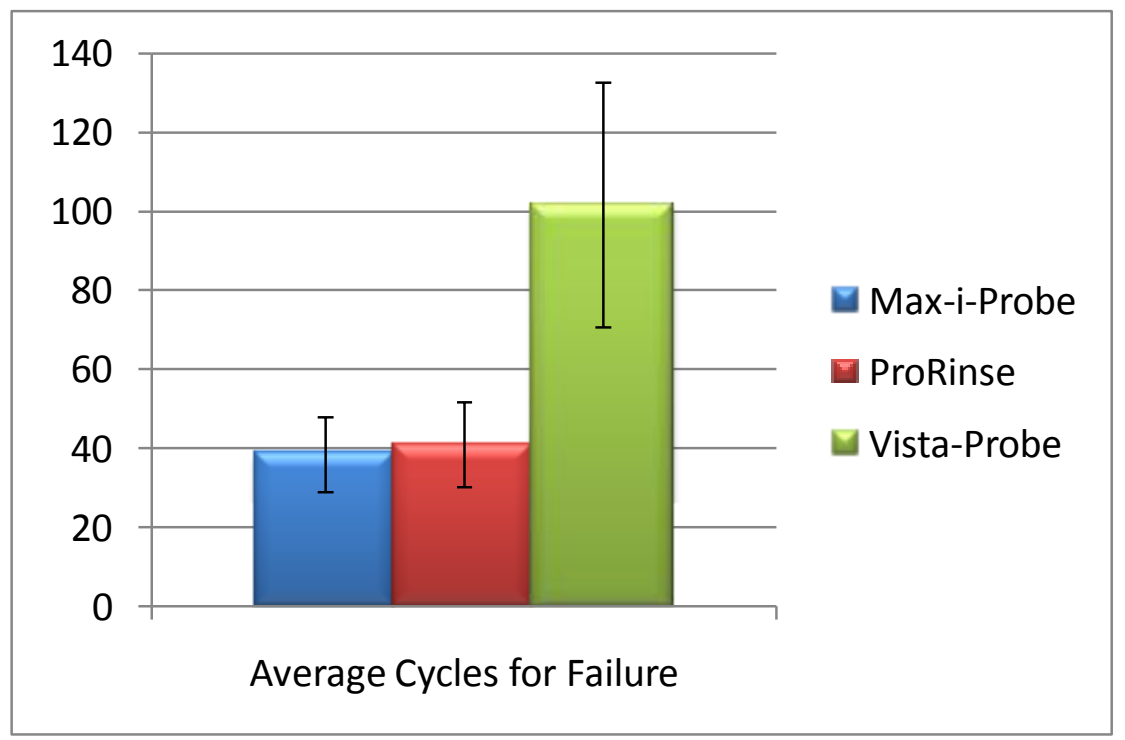

Figure 11. Average number of cycles required for failure.

Additionally, all needles failed at the same location — namely, the proximal side of the side vent.

\section{DISCUSSION}

Advancements in cleaning, shaping, and obturating of the root canal space have created a safer, more effective, and more predictable therapy for retaining the natural dentition. Though shaping and obturating garner much more attention than cleaning, proper irrigation and flushing of the canal contents is paramount.

Thorough cleaning need meet but a few requirements; however, many clinicians fail to employ these fundamental techniques.

The canal contents must be thoroughly irrigated to allow for the greatest reduction in bacterial load as possible. Bacteria are chiefly responsible for pathosis $(1,2,4,12,13$, $14,15)$. Instrumentation decreases bacterial loads, but irrigant is necessary for thorough reduction $(3,16,17)$. Each root canal system must be properly instrumented to a minimum size of $0.30 \mathrm{~mm}$ for irrigant to passively reach the apex (6), yet many clinicians leave apical preparations much smaller. 
Additionally, infected dentin and cementum chips must be flushed from the root canal space $(18,19,20)$. Numerous studies have proven that effective flushing of debris occurs no greater than one $\mathrm{mm}$ from the irrigating needle's terminus $(7,8)$. If irrigation is only occurring within the pulp chamber or in the coronal two-thirds of the root canal system, much debris will be inadvertently left at the apex. This debris could interfere with a proper apical seat and seal; additionally, remaining debris might continue to evoke an inflammatory response and prevent proper repair.

Finally, the irrigants must be contained within the root canal system, and any expression beyond the terminus of the apex might result in severe, painful consequences as is evidenced in numerous case reports (32-36).

In order to accomplish the three aforementioned goals, irrigating needles must be closely approximated to the apex without increasing dangerous apical forces. The Max-iProbe, ProRinse, and Vista-Probe are size 30-gauge irrigating needles, have a side vent, and have a safe end. These important features allow for safer, more effective irrigation as supported by the literature $(37,39)$.

However, the presence of the side vent has its disadvantage. This intentional defect in the surface of the needle creates a "weak point" that might result in failure and separation in the root canal system during typical usage (9).

The mean length of the side vent was comparable between the Max-i-Probe and ProRinse samples, though the Vista-Probe sample had a shorter mean length. The mean number of cycles resulted in similar findings: the Max-i-Probe and ProRinse were comparable, while the Vista-Probe required substantially more cycles.

It was hypothesized that no significant influence would be noted between the length of the side vent and the number of cycles required for flexural fatigue and failure. Also, it was hypothesized that no needle would require significantly more cycles and thus be clinically "safer" as it relates to flexural fatigue.

Using bivariate fit, the side length of each irrigating needle and the number of cycles required for failure were plotted to evaluate correlation. No significant correlation was noted when evaluating the individual files within each group ( $p>0.05)$; thus, the first null hypothesis was supported. Side vent length does not appear to greatly influence the number of cycles required for flexural fatigue and failure. 
However, the Vista-probe irrigating needle required a significantly greater number of flexing cycles to produce flexural fatigue and failure $(\mathrm{p}<0.001)$, thus failing to support the second null hypothesis. The Vista-Probe irrigating needle appears clinically "safer" than the Max-i-Probe and ProRinse irrigating needles as it relates to flexural fatigue.

It is unknown exactly what differences in needle make-up or design allow for the Vista-Probe to undergo more flexing. The thickness of the needle's medal may differ between the different brands, which may influence the ability to flex before failure occurs.

Additionally, the length of the side vent might be only important as it relates to the position on the irrigating needle. As a result of the Vista-Probe's smaller side vent length, the proximal side of the vent is much closer to the tip. Perhaps this difference may favor the Vista-Probe when flexural fatigue is evaluated. The flexure might fatally stress the "weak" side vent location sooner the closer the side vent is located to the tip. Further tests are needed to verify any other aspects of these needle designs that may influence flexural fatigue and failure.

Flexing cycles creating instrument failure in a simulated root canal system would create a more realistic and relevant clinical setting. However, pilot studies attempting such proved unsuccessful. The irrigating probes appeared to alter the shape of curved canals, thus removing any standardization within the study's design. The proximal edge of the side vent would engage and alter canal wall anatomy upon insertion, and the distal edge of the side vent would do the same upon removal.

It is possibly this mechanism that creates the greatest risk for needle failure and separation within the root canal system. It is surmised that as the needle weakens due to flexural fatigue during typical usage, the side vent edge engages the canal wall upon removal, which causes failure and separation. This catastrophic event might be influenced by side vent length, though not as a result of flexural fatigue but rather increased frictional forces due to a longer side vent. The longer side vent might create a larger edge which could engage more readily in the root canal system's dentinal wall. 
Further studies are indicated that would address irrigating needle failure and separation as it relates to frictional forces in curved canals. A properly designed in vitro study using a realistic root canal system that allowed for standardization would be ideal. Finally, separation of irrigating needles remains a relatively rare occurrence. Newer irrigation techniques are continually being developed that promise improvements. One such is the apical negative pressure irrigating technique in which the irrigant floods the chamber and is removed via a needle placed to working length. The irrigant is thus drawn to the apex to be suctioned and requires no movement of the irrigating needle in an in and out motion. No potentially dangerous positive pressure is required to irrigate the apical regions of the tooth. Results are promising, and as advances in needle design, material properties, and means of delivery occur, a safer, more effective method of irrigation and flushing can take place. 


\section{CHAPTER V SUMMARY AND CONCLUSIONS}

\section{SUMMARY}

In an effort to produce better, more predictable results, irrigation techniques, materials, and instruments continue to evolve. This study looked at three 30-gauge endodontic irrigating needles with closed ends and a side vent port, which show much promise in improving endodontic therapy and are widely used. The purpose of this study was to evaluate the influence of the irrigating needle's side vent length on flexural fatigue and eventual failure.

It was hypothesized that no significant influence would be noted when comparing side vent lengths to the number of cycles required for flexural fatigue and failure. Additionally, it was hypothesized that no significant difference would be noted between any of the irrigating needle groups as it relates to the number of cycles required for flexural fatigue, thus suggesting that different needles do not present a "safer" instrument.

Only the first null hypothesis was fully supported. The length of the irrigating needle's side vent did not significantly influence the number of cycles required for failure. However, the second null hypothesis was rejected. There was a significant difference noted in the number of cycles required to induce flexural fatigue and failure in the Vista-Probe as compared to the Max-i-Probe and ProRinse irrigating needles. Thus, the Vista-Probe appears to present a "safer" instrument as it relates to flexural fatigue.

The statistical analysis was performed using bivariate fit, one-way ANOVA, and Tukey's HSD tests. 


\section{CONCLUSIONS}

This in-vitro study showed that the side vent length has no significant influence on the number of cycles required for flexural fatigue and failure. Also, the Vista-Probe requires a significantly greater number of cycles for flexural fatigue as compared to the Max-i-Probe and ProRinse irrigating needles, thus suggesting a safer instrument. 


\section{REFERENCES}

1. Kakehashi S, Stanley HR, Fitzgerald RJ. The effects of surgical exposures of dental pulps in germ-free and conventional laboratory rats. Oral Surg Oral Med Oral Pathol $1965 ; 20: 340-9$.

2. Möller AJ, Fabricius L, Dahlén G, Ohman AE, Heyden G. Influence on periapical tissues of indigenous oral bacteria and necrotic pulp tissue in monkeys. Scand J Dent Res 1981; 89(6):475-84.

3. Byström A, Sundqvist G. Bacteriologic evaluation of the efficacy of mechanical root canal instrumentation in endodontic therapy. Scand J Dent Res 1981; 89(4):321-8.

4. Sundqvist G. Bacterial studies of necrotic dental pulps. Umae Univ Odontological Dissertations 1976; 7:1-93.

5. Ram Z. Effectiveness of root canal irrigation. Oral Surg Oral Med Oral Pathol 1977; 44(2):306-12.

6. Salzgeber RM, Brilliant JD. An in vivo evaluation of the penetration of an irrigating solution in root canals. J Endod 1977; (3)10:394-8.

7. Abou-Rass M, Piccinino MV. The effectiveness of four clinical irrigation methods on the removal of root canal debris. Oral Surg Oral Med Oral Pathol 1982; 54(3):323-8.

8. Chow TW. Mechanical effectiveness of root canal irrigation. J Endod 1983; 9(11):475-9.

9. Stowe, T. Personal communication. 1 February 2008.

10. Strindberg LA. Dependence of the results of pulp therapy on certain factors. Acta Odont Scand 1956; 14:78.

11. McQuillen JR. Editorial--Who first filled nerve cavities? Dent Cosmos 1862; 3:556557.

12. Baumgartner JC, Falkler WA Jr. Bacteria in the apical $5 \mathrm{~mm}$ of infected root canals. J Endod 1991; 17(8):380-3. 
13. Seltzer S, Farber PA. Microbiology factors in endodontology. Oral Surg Oral Med Oral Pathol 1994; 78(5):634-45.

14. Siqueira JF Jr. Endodontic infections: concepts, paradigms, and perspectives. Oral Surg Oral Med Oral Pathol Oral Radiol Endod 2002; 94(3):281-93.

15. Sjögren U, Figdor D, Persson S, Sundqvist G. Influence of infection at the time of root filling on the outcome of endodontic treatment of teeth with apical periodontitis. Int Endod J 1997; 30(5):297-306.

16. Dalton BC, Orstavik D, Phillips C, Pettiette M, Trope M. Bacterial reduction with nickel-titanium rotary instrumentation. J Endod 1998; 24(11):763-7.

17. Siqueira JF Jr, Lima KC, Magalhães FA, Lopes HP, de Uzeda M. Mechanical reduction of the bacterial population in the root canal by three instrumentation techniques. J Endod 1999; 25(5):332-5.

18. Holland R, De Souza V, Nery MJ, de Mello W, Bernabé PF, Otoboni Filho JA. Tissue reactions following apical plugging of the root canal with infected dentin chips. A histologic study in dogs' teeth. Oral Surg Oral Med Oral Pathol 1980; 49(4):366-9.

19. Yusuf $H$. The significance of the presence of foreign material periapically as a cause of failure of root treatment. Oral Surg Oral Med Oral Pathol 1982; 54(5): 566-74.

20. Ariizumi Y, Yoshida T, Murakami K, Kato S, Fukuro K, Kaneko S, Nakagawa KI, Asai Y. Histopathological studies of periodontal tissue reactions following apical plugging with autogenous dentin chips. Shikwa Gakuho 1990; 90(3):421-8.

21. Zehnder M. Root canal irrigants. J Endod 2006; 32(5):389-98.

22. Senia ES, Marshall FJ, Rosen S. The solvent action of sodium hypochlorite on pulp tissue of extracted teeth. Oral Surg Oral Med Oral Pathol 1971; 31(1):96-103.

23. Harrison JW. Irrigation of the root canal system. Dent Clin North Am 1984; 28(4):797-808.

24. Hand RE, Smith RL, Harrison JW. Analysis of the effect of dilution on the necrotic tissue dissolution property of sodium hypochlorite. J Endod 1978; 4(2):60-4.

25. Walton RE, Torabinejad M. Principles and practice of endodontics. Philadelphia: WB Saunders; 1989.

26. Baker N, Eleazer P, Averbach R, Seltzer S. Scanning electron microscopic study of the efficacy of various irrigating solutions. J Endod 1975; 1(4):127-35. 
27. Moser JB, Heuer MA. Forces and efficacy in endodontic irrigation systems. Oral Surg Oral Med Oral Pathol 1982; 53(4):425-8.

28. Goldman LB, Goldman M, Kronman JH, Lin PS. Scanning electron microscope study of a new irrigation method in endodontic treatment. Oral Surg Oral Med Oral Pathol 1979; 48(1):79-83.

29. Drobotij E, Grower M, Peters D, Lorton L, Bernier W. Comparison of the flushing effectiveness of four different types of needles after root canal preparation. J Endod 1980; 6(12): 870-5.

30. Abou-Rass M, Patonai FJ Jr. The effects of decreasing surface tension on the flow of irrigating solutions in narrow root canals. Oral Surg Oral Med Oral Pathol 1982; 53(5):524-6.

31. Bradford CE, Eleazer PD, Downs KE, Scheetz JP. Apical pressures developed by needles for canal irrigation. J Endod 2002; 28(4):333-5.

32. Becker GL, Cohen S, Borer R. The sequelae of accidentally injecting sodium hypochlorite beyond the root apex. Report of a case. Oral Surg Oral Med Oral Pathol 1974; 38(4):633-8.

33. Kaufman AY. Facial emphysema caused by hydrogen peroxide irrigation: report of a case. J Endod 1981; 7(10):470-2.

34. Kaufman AY, Keila S. Hypersensitivity to sodium hypochlorite. J Endod 1989; 15(5):224-6.

35. Reeh ES, Messer HH. Long-term paresthesia following inadvertent forcing of sodium hypochlorite through perforation in maxillary incisor. Endod Dent Traumatol 1989; 5(4):200-3.

36. Gatot A, Arbelle J, Leiberman A, Yanai-Inbar I. Effects of sodium hypochlorite on soft tissues after its inadvertent injection beyond the root apex. J Endod 1991; 17(11):573-4.

37. Sinanan SK, Marshall FJ, Quinton-Cox R. The effectiveness of irrigation in endodontics. J Can Dent Assoc 1983; 49(11):771-6.

38. Teplitsky PE, Chenail BL, Mack B, Machnee CH. Endodontic irrigation-a comparison of endosonic and syringe delivery systems. Int Endod J 1987; 20(5):23341.

39. Kahn FH, Rosenburg PA, Gliksberg J. An in vitro evaluation of the irrigating characteristics of ultrasonic and subsonic handpieces and irrigating needles and probes. J Endod 1995; 21(5):277-80. 
40. Kahn FH, Rosenberg PA, Schertzer L, Korthals G, Nguyen PN. An in-vitro evaluation of sealer placement methods. Int Endod J 1997; 30(3):181-6.

41. Sedgley C, Applegate B, Nagel A, Hall D. Real-time imaging and quantification of bioluminescent bacteria in root canals in vitro. J Endod 2004; 30(12):893-8.

42. Sedgley CM, Nagel AC, Hall D, Applegate B. Influence of irrigant needle depth in removing bioluminescent bacteria inoculated into instrumented root canals using realtime imaging in vitro. J Endod 2005; 38(2):97-104.

43. Vinothkumar TS, Kavitha S, Lakshminarayanan L, Gomathi NS, Kumar V. Influence of irrigating needle-tip designs in removing bacteria inoculated into instrumented root canals measured using single-tube luminometer. J Endod 2007; 33(6):746-8.

44. Hsieh YD, Gau CH, Kung Wu SF, Shen EC, Hsu PW, Fu E. Dynamic recording of irrigating fluid distribution in root canals using thermal image analysis. Int Endod $\mathrm{J}$ 2007; 40(1):11-7.

45. Segall RO, del Rio CE, Brady JM, Ayer WA. Evaluation of endodontic instruments as received from the manufacturer: the demand for quality control. Oral Surg Oral Med Oral Pathol 1977; 44(3):463-7.

46. Sotokawa T. An analysis of clinical breakage of root canal instruments. J Endod $1988 ; 14(2): 75-82$.

47. Crump MC, Natkin E. Relationship of broken root canal instruments to endodontic case prognosis: a clinical investigation. J Am Dent Assoc 1970; 80(6):1341-7.

48. Tamse A, Katz A. Separating instrument technique for root canal filing: a case report. Int Endod J 1987; 20(6):295-7. 


\section{SUPPLEMENTAL READINGS}

Cohen S, Hargreaves KM. Pathways of the Pulp. $9^{\text {th }}$ ed. St. Louis: Mosby, 2006.

Ingle JI, Bakland LK, Baumgartner JC. Ingle's Endodontics. $6^{\text {th }}$ ed. Hamilton: B.C. Decker Inc, 2008. 


\section{APPENDIX A \\ DATA FOR MAX-I-PROBE IRRIGATING NEEDLES}


TABLE 1.

DATA FOR MAX-I-PROBE IRRIGATING NEEDLES (23)

\begin{tabular}{|c|c|c|c|c|c|r|r|}
\hline & $\begin{array}{c}\text { Blinded } \\
\text { Number }\end{array}$ & $\begin{array}{c}\text { SO } \\
\text { Number }\end{array}$ & $\begin{array}{c}\text { SL } \\
\text { Number }\end{array}$ & $\begin{array}{c}\text { Tip length } \\
\text { to side vent } \\
\text { end (mm) } \\
\text { A }\end{array}$ & $\begin{array}{c}\text { Tip length } \\
\text { to side vent } \\
\text { start (mm) } \\
\text { B }\end{array}$ & $\begin{array}{c}\text { Side vent } \\
\text { length } \\
\text { (mm) } \\
\text { A - B }\end{array}$ & $\begin{array}{c}\text { Number } \\
\text { of } 30^{\circ} \\
\text { bends for } \\
\text { failure }\end{array}$ \\
\hline 1 & 4 & $41297 \mathrm{~A}$ & $230458 \mathrm{M}$ & 1.757 & 0.830 & 0.927 & 34 \\
\hline 2 & 7 & $41297 \mathrm{~A}$ & $230335 \mathrm{M}$ & 1.711 & 0.841 & 0.870 & 42 \\
\hline 3 & 8 & $41297 \mathrm{~A}$ & $229875 \mathrm{M}$ & 2.059 & 1.077 & 0.982 & 46 \\
\hline 4 & 11 & $41297 \mathrm{~A}$ & $230334 \mathrm{M}$ & 1.955 & 0.999 & 0.956 & 48 \\
\hline 5 & 14 & $41799 \mathrm{~A}$ & $231122 \mathrm{M}$ & 2.117 & 1.057 & 1.060 & 48 \\
\hline 6 & 15 & $41799 \mathrm{~A}$ & $231124 \mathrm{M}$ & 2.032 & 1.086 & 0.946 & 48 \\
\hline 7 & 16 & $41799 \mathrm{~A}$ & $228763 \mathrm{M}$ & 1.815 & 0.921 & 0.894 & 32 \\
\hline 8 & 17 & $41799 \mathrm{~A}$ & $231123 \mathrm{M}$ & 2.098 & 1.078 & 1.020 & 42 \\
\hline 9 & 21 & $42183 \mathrm{~A}$ & $231720 \mathrm{M}$ & 1.766 & 0.850 & 0.916 & 38 \\
\hline 10 & 22 & $42183 \mathrm{~A}$ & $231721 \mathrm{M}$ & 1.876 & 0.900 & 0.976 & 42 \\
\hline 11 & 24 & $42183 \mathrm{~A}$ & $231649 \mathrm{M}$ & 2.073 & 1.068 & 1.005 & 32 \\
\hline 12 & 25 & $42183 \mathrm{~A}$ & $231719 \mathrm{M}$ & 1.955 & 0.990 & 0.965 & 50 \\
\hline 13 & 35 & $44152 \mathrm{~A}$ & $234911 \mathrm{M}$ & 1.776 & 0.769 & 1.007 & 21 \\
\hline 14 & 36 & $44152 \mathrm{~A}$ & $324926 \mathrm{M}$ & 1.941 & 1.017 & 0.924 & 58 \\
\hline 15 & 38 & $44152 \mathrm{~A}$ & $234912 \mathrm{M}$ & 1.846 & 0.872 & 0.974 & 24 \\
\hline 16 & 39 & $42741 \mathrm{~A}$ & $232273 \mathrm{M}$ & 1.997 & 1.109 & 0.888 & 28 \\
\hline 17 & 43 & $42741 \mathrm{~A}$ & $232271 \mathrm{M}$ & 1.843 & 0.994 & 0.849 & 24 \\
\hline 18 & 45 & $42741 \mathrm{~A}$ & $232272 \mathrm{M}$ & 1.987 & 0.911 & 1.076 & 44 \\
\hline 19 & 47 & $41589 \mathrm{~A}$ & $230848 \mathrm{M}$ & 2.101 & 1.076 & 1.025 & 34 \\
\hline 20 & 49 & $41589 \mathrm{~A}$ & $231121 \mathrm{M}$ & 1.992 & 1.041 & 0.951 & 45 \\
\hline 21 & 50 & $41589 \mathrm{~A}$ & $230849 \mathrm{M}$ & 1.983 & 0.950 & 1.033 & 40 \\
\hline 22 & 57 & $43156 \mathrm{~A}$ & $233425 \mathrm{M}$ & 2.071 & 1.214 & 0.857 & 30 \\
\hline 23 & 58 & $43156 \mathrm{~A}$ & $233426 \mathrm{M}$ & 1.833 & 0.955 & 0.878 & 36 \\
\hline
\end{tabular}


APPENDIX B

DATA FOR PRORINSE IRRIGATING NEEDLES 
TABLE 2.

DATA FOR PRORINSE IRRIGATING NEEDLES (20)

\begin{tabular}{|r|r|l|l|r|r|r|r|}
\hline & $\begin{array}{c}\text { Blinded } \\
\text { Number }\end{array}$ & $\begin{array}{c}\text { SO } \\
\text { Number }\end{array}$ & $\begin{array}{c}\mathrm{SL} \\
\text { Number }\end{array}$ & $\begin{array}{c}\text { Tip length } \\
\text { to side vent } \\
\text { end }(\mathrm{mm}) \\
\mathrm{A}\end{array}$ & $\begin{array}{c}\text { Tip length } \\
\text { to side vent } \\
\text { start }(\mathrm{mm}) \\
\mathrm{B}\end{array}$ & $\begin{array}{c}\text { Side vent } \\
\text { length } \\
\text { (mm) } \\
\mathrm{A}-\mathrm{B}\end{array}$ & $\begin{array}{c}\text { Number } \\
\text { of } 30^{\circ} \\
\text { bends for } \\
\text { failure }\end{array}$ \\
\hline 1 & 1 & $41140 \mathrm{~A}$ & $229993 \mathrm{P}$ & 1.663 & 0.771 & 0.892 & 47 \\
\hline 2 & 2 & $41140 \mathrm{~A}$ & $229994 \mathrm{P}$ & 1.938 & 1.089 & 0.849 & 54 \\
\hline 3 & 6 & $41297 \mathrm{~A}$ & $230459 \mathrm{P}$ & 1.906 & 0.987 & 0.919 & 41 \\
\hline 4 & 9 & $41297 \mathrm{~A}$ & $230460 \mathrm{P}$ & 1.955 & 1.022 & 0.933 & 52 \\
\hline 5 & 13 & $41297 \mathrm{~A}$ & $230416 \mathrm{P}$ & 1.911 & 0.930 & 0.981 & 38 \\
\hline 6 & 20 & $42183 \mathrm{~A}$ & $231924 \mathrm{P}$ & 1.894 & 0.984 & 0.910 & 32 \\
\hline 7 & 23 & $42183 \mathrm{~A}$ & $231925 \mathrm{P}$ & 1.859 & 0.996 & 0.863 & 26 \\
\hline 8 & 31 & $43444 \mathrm{~A}$ & $234172 \mathrm{P}$ & 1.747 & 0.905 & 0.842 & 30 \\
\hline 9 & 32 & $43444 \mathrm{~A}$ & $234174 \mathrm{P}$ & 1.977 & 1.059 & 0.918 & 58 \\
\hline 10 & 33 & $43444 \mathrm{~A}$ & $234173 \mathrm{P}$ & 1.981 & 1.011 & 0.970 & 50 \\
\hline 11 & 40 & $42741 \mathrm{~A}$ & $232275 \mathrm{P}$ & 1.922 & 0.975 & 0.947 & 32 \\
\hline 12 & 41 & $42741 \mathrm{~A}$ & $232277 \mathrm{P}$ & 1.920 & 1.000 & 0.920 & 43 \\
\hline 13 & 44 & $42741 \mathrm{~A}$ & $232276 \mathrm{P}$ & 1.994 & 1.061 & 0.933 & 34 \\
\hline 14 & 46 & $42741 \mathrm{~A}$ & $232920 \mathrm{P}$ & 1.876 & 0.992 & 0.884 & 32 \\
\hline 15 & 48 & $41589 \mathrm{~A}$ & $230461 \mathrm{P}$ & 1.875 & 0.900 & 0.975 & 36 \\
\hline 16 & 51 & $41589 \mathrm{~A}$ & $230462 \mathrm{P}$ & 1.801 & 0.843 & 0.958 & 44 \\
\hline 17 & 55 & $43156 \mathrm{~A}$ & $233324 \mathrm{P}$ & 1.900 & 0.953 & 0.947 & 46 \\
\hline 18 & 56 & $43156 \mathrm{~A}$ & $233325 \mathrm{P}$ & 1.717 & 0.770 & 0.947 & 62 \\
\hline 19 & 59 & & $234173 \mathrm{P}$ & 1.899 & 0.972 & 0.927 & 28 \\
\hline 20 & 60 & & $234172 \mathrm{P}$ & 1.888 & 0.994 & 0.894 & 35 \\
\hline
\end{tabular}


APPENDIX C

DATA FOR VISTA-PROBE IRRIGATING NEEDLES 
TABLE 3.

DATA FOR VISTA-PROBE IRRIGATING NEEDLES (20)

\begin{tabular}{|r|r|r|l|r|r|r|r|}
\hline & $\begin{array}{c}\text { Blinded } \\
\text { Number }\end{array}$ & $\begin{array}{c}\text { SO } \\
\text { Number }\end{array}$ & $\begin{array}{c}\text { SL } \\
\text { Number }\end{array}$ & $\begin{array}{c}\text { Tip length } \\
\text { to side vent } \\
\text { end }(\mathrm{mm}) \\
\mathrm{A}\end{array}$ & $\begin{array}{c}\text { Tip length } \\
\text { to side vent } \\
\text { start }(\mathrm{mm}) \\
\mathrm{B}\end{array}$ & $\begin{array}{c}\text { Side vent } \\
\text { length } \\
(\mathrm{mm}) \\
\mathrm{A}-\mathrm{B}\end{array}$ & $\begin{array}{c}\text { Number } \\
\text { of } 30^{\circ} \\
\text { bends for } \\
\text { failure }\end{array}$ \\
\hline 1 & 3 & $315130 \mathrm{~V}$ & $315130 \mathrm{~V}$ & 1.560 & 0.974 & 0.586 & 159 \\
\hline 2 & 5 & $315130 \mathrm{~V}$ & $315130 \mathrm{~V}$ & 1.541 & 0.938 & 0.603 & 116 \\
\hline 3 & 10 & $315130 \mathrm{~V}$ & $315130 \mathrm{~V}$ & 1.560 & 0.972 & 0.588 & 172 \\
\hline 4 & 12 & $315130 \mathrm{~V}$ & $315130 \mathrm{~V}$ & 1.515 & 0.895 & 0.620 & 137 \\
\hline 5 & 18 & $315130 \mathrm{~V}$ & $315130 \mathrm{~V}$ & 1.569 & 0.940 & 0.629 & 72 \\
\hline 6 & 19 & $315130 \mathrm{~V}$ & $315130 \mathrm{~V}$ & 1.638 & 1.075 & 0.563 & 93 \\
\hline 7 & 26 & $315130 \mathrm{~V}$ & $315130 \mathrm{~V}$ & 1.522 & 0.934 & 0.588 & 92 \\
\hline 8 & 27 & $315130 \mathrm{~V}$ & $315130 \mathrm{~V}$ & 1.585 & 0.958 & 0.627 & 86 \\
\hline 9 & 28 & $315130 \mathrm{~V}$ & $315130 \mathrm{~V}$ & 1.676 & 0.995 & 0.681 & 98 \\
\hline 10 & 29 & $315130 \mathrm{~V}$ & $315130 \mathrm{~V}$ & 1.546 & 0.951 & 0.595 & 114 \\
\hline 11 & 30 & $315130 \mathrm{~V}$ & $315130 \mathrm{~V}$ & 1.540 & 0.951 & 0.589 & 112 \\
\hline 12 & 34 & $315130 \mathrm{~V}$ & $315130 \mathrm{~V}$ & 1.514 & 0.896 & 0.618 & 92 \\
\hline 13 & 37 & $315130 \mathrm{~V}$ & $315130 \mathrm{~V}$ & 1.527 & 0.947 & 0.580 & 107 \\
\hline 14 & 42 & $315130 \mathrm{~V}$ & $315130 \mathrm{~V}$ & 1.585 & 0.977 & 0.608 & 126 \\
\hline 15 & 52 & $315130 \mathrm{~V}$ & $315130 \mathrm{~V}$ & 1.523 & 0.951 & 0.572 & 86 \\
\hline 16 & 53 & $315130 \mathrm{~V}$ & $315130 \mathrm{~V}$ & 1.591 & 1.008 & 0.583 & 65 \\
\hline 17 & 54 & $315130 \mathrm{~V}$ & $315130 \mathrm{~V}$ & 1.492 & 0.909 & 0.583 & 74 \\
\hline 18 & 61 & $315130 \mathrm{~V}$ & $315130 \mathrm{~V}$ & 1.506 & 0.906 & 0.600 & 90 \\
\hline 19 & 62 & $315130 \mathrm{~V}$ & $315130 \mathrm{~V}$ & 1.607 & 1.035 & 0.572 & 41 \\
\hline 20 & 63 & $315130 \mathrm{~V}$ & $315130 \mathrm{~V}$ & 1.506 & 0.882 & 0.624 & 102 \\
\hline
\end{tabular}


APPENDIX D

STATISTICAL ANALYSES 


\section{BIVARIATE FIT OF NUMBER OF CYCLES FOR FAILURE BY SIDE VENT LENGTH}
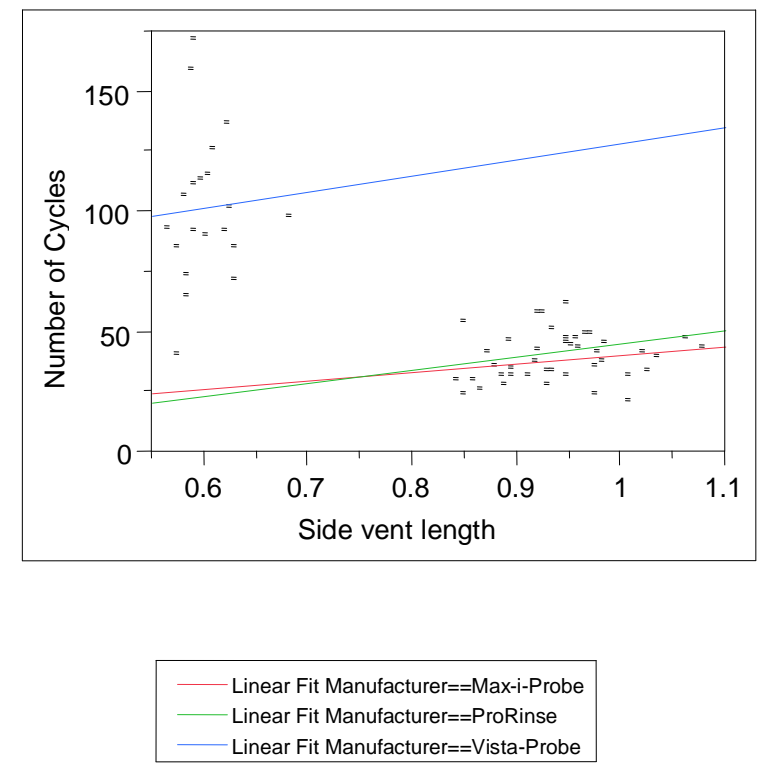

\section{Linear Fit Manufacturer $==$ Max-i-Probe}

Number of cycles $=3.9252153+36.203651^{*}$ Side vent length

\section{Summary of Fit}

RSquare

RSquare Adj

Root Mean Square Error

Mean of Response

Observations (or Sum Wgts)
0.061378

0.016682

9.435219

38.52174

\section{Analysis of Variance}

Source DF

Model

Error

DF Sum of Squares

122.2487

1869.4904

C. Total

21

22

1991.7391

$\begin{array}{rr}\text { Mean Square } & \text { F Ratio } \\ 122.249 & 1.3732 \\ 89.023 & \text { Prob }>\text { F } \\ & 0.2544\end{array}$

Parameter Estimates

Term

Intercept

Length of
Estimate

3.9252153

36.203651
Std Error
29.5886

30.89457 t Ratio
0.13
1.17

Prob $>|\mathbf{t}|$

0.8957

0.2544 


\section{BIVARIATE FIT OF NUMBER OF CYCLES FOR FAILURE BY SIDE VENT LENGTH}
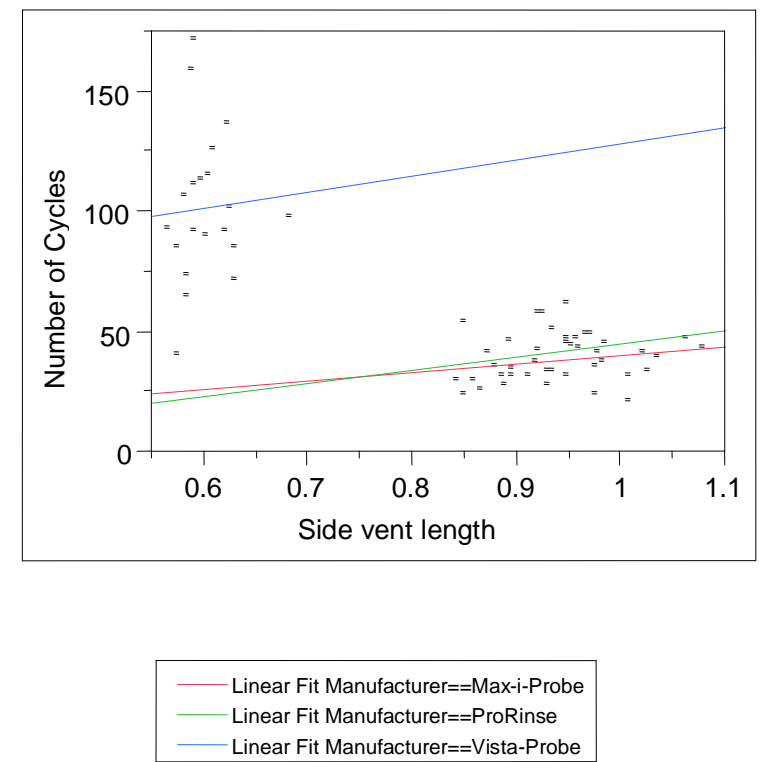

Linear Fit Manufacturer $==$ ProRinse

Number of cycles $=-9.837231+55.226266^{*}$ Side vent length

\section{Summary of Fit}

RSquare

RSquare Adj

Root Mean Square Error

Mean of Response

Observations (or Sum Wgts)
0.045322

$-0.01084$

10.73477

41

19

\section{Analysis of Variance}

\section{Source \\ DF}

Model

Error

C. Total

1

17

Sum of Squares

93.0010

1958.9990

2052.0000

$\begin{array}{rr}\text { Mean Square } & \text { F Ratio } \\ 93.001 & 0.8071 \\ 115.235 & \text { Prob > F } \\ & 0.3815\end{array}$

\section{Parameter Estimates}

Term

Intercept

Length of
Estimate

$-9.837231$

55.226266
Std Error

56.64238

61.47442

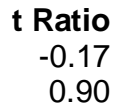

Prob $>|t|$

0.8642

0.3815 


\section{BIVARIATE FIT OF NUMBER OF CYCLES FOR FAILURE BY SIDE VENT LENGTH}
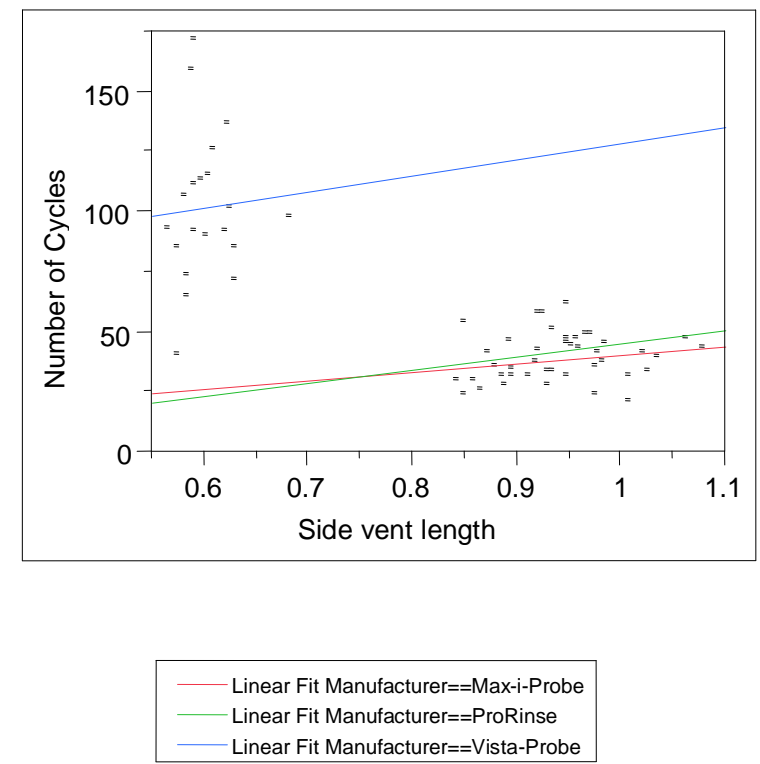

Linear Fit Manufacturer $==$ Vista-Probe

Number of cycles $=61.654182+66.693011^{*}$ Side vent length

\section{Summary of Fit}

RSquare

RSquare Adj

Root Mean Square Error

Mean of Response

Observations (or Sum Wgts)

$$
\begin{array}{r}
0.003444 \\
-0.05192 \\
31.69098 \\
101.7
\end{array}
$$

\section{Analysis of Variance}

\section{Source \\ DF}

Model

Error

C. Total

18

18

19

Sum of Squares

62.471

18077.729

18140.200

$\begin{array}{rr}\text { Mean Square } & \text { F Ratio } \\ 62.47 & 0.0622 \\ 1004.32 & \text { Prob > F } \\ & 0.8059\end{array}$

\section{Parameter Estimates}

Term

Intercept

Length of
Estimate

61.654182 66.693011
Std Error

160.7219

267.4087
t Ratio
0.38
0.25

Prob $>|\mathbf{t}|$

0.7058

0.8059 
Response Number of Cycles for Failure

Whole Model

Actual by Predicted Plot

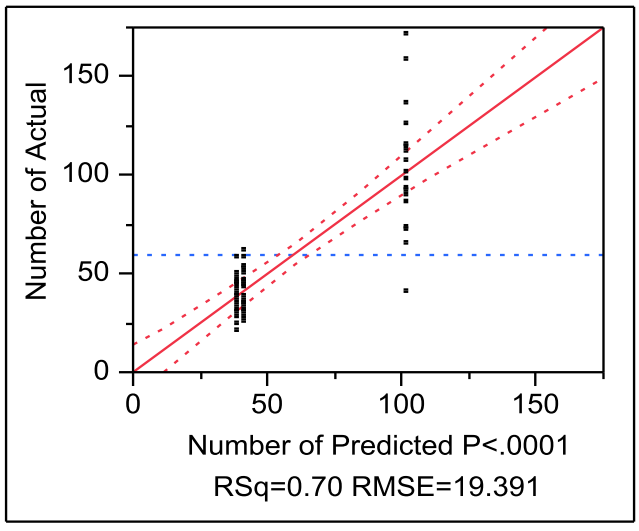

\section{Summary of Fit}

$\begin{array}{lr}\text { RSquare } & 0.701924 \\ \text { RSquare Adj } & 0.69182 \\ \text { Root Mean Square Error } & 19.39069 \\ \text { Mean of Response } & 59.66129 \\ \text { Observations (or Sum Wgts) } & 62\end{array}$

$\begin{array}{lrrrr}\begin{array}{l}\text { Analysis of Variance } \\ \text { Source }\end{array} & \text { DF } & \text { Sum of Squares } & \text { Mean Square } & \text { F Ratio } \\ \text { Model } & 2 & 52239.948 & 26120.0 & 69.4682 \\ \text { Error } & 59 & 22183.939 & 376.0 & \text { Prob > F } \\ \text { C. Total } & 61 & 74423.887 & & <.0001^{*}\end{array}$

\section{Effect Tests}

Source Nparm DF Sum of Squares

Manufacturer

$\begin{array}{rrr}\text { Nparm } & \text { DF } & \text { Sum of Squares } \\ 2 & 2 & 52239.948\end{array}$

\section{Residual by Predicted Plot}

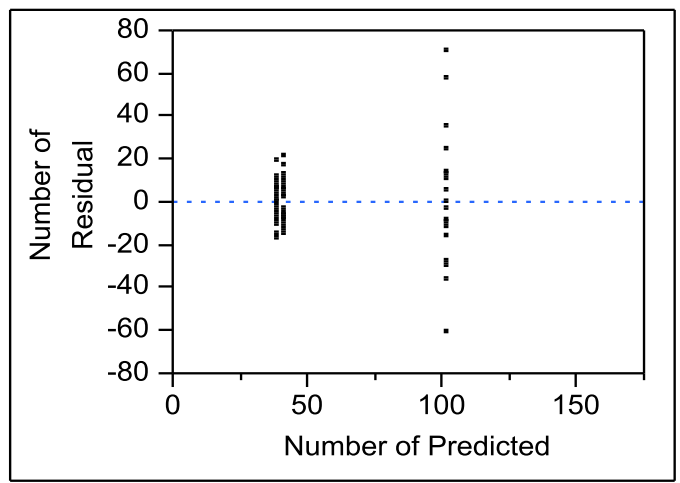




\section{Manufacturer \\ Leverage Plot}

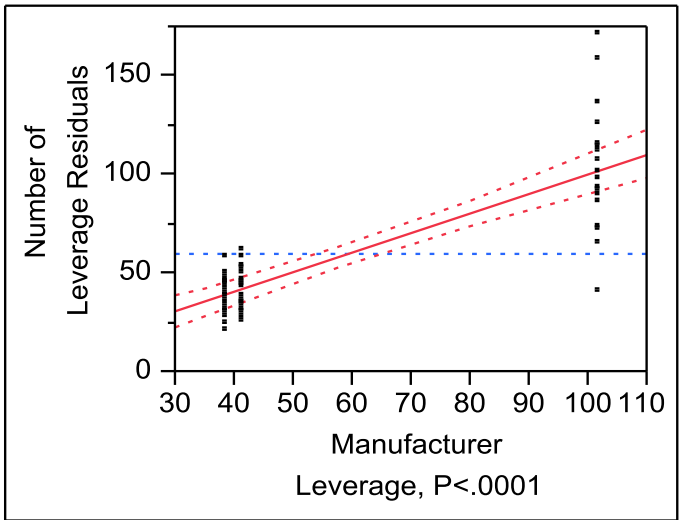

\section{Least Squares Means Table}

$\begin{array}{lrrr}\text { Level } & \text { Least Sq Mean } & \text { Std Error } & \text { Mean } \\ \mathrm{M} & 38.52174 & 4.0432390 & 38.522 \\ \mathrm{P} & 41.00000 & 4.4485300 & 41.000 \\ \mathrm{~V} & 101.70000 & 4.3358907 & 101.700\end{array}$

\section{LS Means Plot}

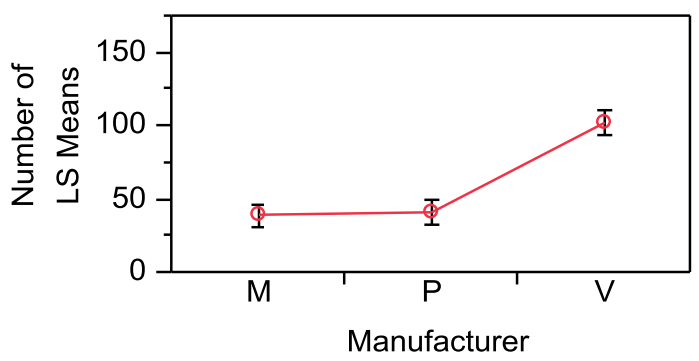




\section{LSMeans Differences Tukey HSD}

$\alpha=$

$0.050 \mathrm{Q}=$

2.40425

LSMean[i] By LSMean[j]

Mean[i]-Mean[j]

Std Err Dif

Lower CL Dif

Upper CL Dif

M

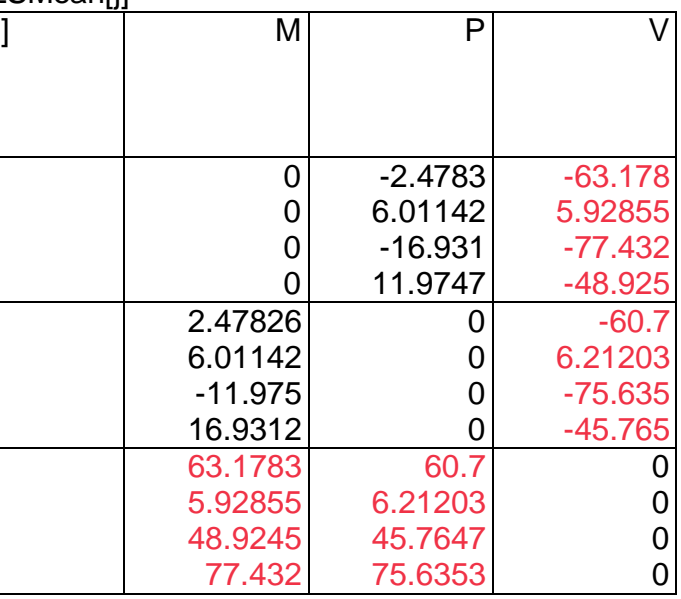

$\begin{array}{lrrr}\text { Level } & & & \text { Least Sq Mean } \\ \text { V } & \text { A } & & 101.70000 \\ \text { P } & & \text { B } & 41.00000 \\ \text { M } & & \text { B } & 38.52174\end{array}$

Levels not connected by same letter are significantly different. 


\section{CURRICULUM VITAE}

Bryant William Stowe, D.D.S.

Personal

Born October 20, 1976 in Ogden, UT

Education

July 2007 to June 2009

West Virginia University

School of Dentistry

Department of Endodontics

Morgantown, WV

Candidate for M.S. in Endodontics

August 2001 to May 2005

West Virginia University

School of Dentistry

Morgantown, WV

D.D.S.

January 1998 to May 2001

Weber State University

Ogden, UT

B.A. in German and History, Minor

in Chemistry

July 2000 to August 2000

University of Utah study abroad

Christian Albrechts University

Kiel, Germany

August 1992 to May 1995

Weber High School

Pleasant View, UT

Work Experience

February 2008 to June 2009

Associate dentist for Dr. Diana Frum

Westover, WV 
July 2005 to June 2007

Dentist at La Clinica del Valle

Medford, OR

\section{Publications}

Stowe TJ, Sedgley CM, Stowe B, Fenno JC. The effects of chlorhexidine gluconate $(0.12 \%)$ on the antimicrobial properties of tooth-colored ProRoot mineral trioxide aggregate. J Endod 2004; 30:429-31.

Digitally signed by John $\mathrm{H}$. 